\title{
Typification of four North American club- chollas: the names of four Engelmannian species from Mexico and Southwestern United States
}

Article

Published Version

Barcenas, R. T., Hawkins, J. and Chiang, F. (2012) Typification of four North American club-chollas: the names of four Engelmannian species from Mexico and Southwestern United States. Haseltonia, 17. pp. 66-69. ISSN 1070-0048 Available at https://centaur.reading.ac.uk/28623/

It is advisable to refer to the publisher's version if you intend to cite from the work. See Guidance on citing.

Publisher: Cactus \& Succulent Society of America

All outputs in CentAUR are protected by Intellectual Property Rights law, including copyright law. Copyright and IPR is retained by the creators or other copyright holders. Terms and conditions for use of this material are defined in the End User Agreement. 


\section{CentAUR}

Central Archive at the University of Reading

Reading's research outputs online 


\title{
TYPIFICATION OF FOUR NORTH AMERICAN CLUB-CHOLLAS: THE NAMES OF FOUR ENGELMANNIAN SPECIES FROM MEXICO AND SOUTHWESTERN UNITED STATES
}

ROLANDO T. BÁRCENAS

Darwin Laboratorium of Molecular Systematics and Evolution, Universidad Autónoma de Querétaro, Facultad de Ciencias Naturales, Av. de la Ciencia s/n, Juriquilla,

Querétaro, México, 76230

e-mail: rtenoch@uaq.mx

JULIE A. HAWKINS

School of Biological Sciences, The University of Reading, Reading, Berkshire, RG6 6AS, U.K. e-mail: j.a.hawkins@reading.ac.uk

FERNANDO CHIANG

Instituto de Biología, UNAM, Circuito Exterior s/n, Del. Coyoacán, México, D.F., 04510 e-mail: chiang@servidor.unam.mx

\begin{abstract}
The names Opuntia bulbispina, O. clavata, O. emoryi and O. grahamii, originally proposed by George Engelmann between 1848 and 1856, are reviewed and typified after new findings of previously unknown voucher specimens. Original materials collected by some of the collaborators employed by Engelmann during the Mexican Boundary Survey were discovered in a loan from the Torrey Herbarium at the New York Botanical Garden (NY). Many of the materials include fragments of stems and fruits, and others include only sectioned flowers and some seeds. Particularly good descriptions of the species here concerned were published in Engelmann's "Synopsis of the Cactaceae" in 1857, and exceptional illustrations were produced by Paulus Roetter and printed in "Cactaceae of the Boundary" in 1859. The problems surrounding some previous typifications of these names range from typification of joint lectotypes to illegitimate typifications of illustrations when original material was known to exist. The materials selected for typification were collected by the Mexican Boundary Survey and are lodged at the herbaria of the Missouri Botanical Garden (MO) and the New York Botanical Garden (NY); some are illustrations published by Engelmann.
\end{abstract}

Resumen: Los nombres de Opuntia bulbispina, O. clavata, O. Emoryi and O. grahamii originalmente propuestos por George Engelmann entre 1848 y 1856 son tipificados después de descubrir nuevos materiales de herbario previamente desconocidos. Los materiales originales colectados por algunos de los colaboradores de Engelmann durante el Estudio de la Frontera Mexicana han sido descubiertos en un préstamo del Herbario Torrey del Jardín Botánico de Nueva York (NY). Los ejemplares encontrados incluyen fragmentos de tallos y frutos así como flores seccionadas y algunas semillas. Las descripciones completas de estas especies fueron publicadas por Englelmann en la "Sinopsis de las Cactaceae" en 1857, e ilustraciones excepcionales fueron elaboradas por Paulus Roetter e incluidas en el reporte "Cactaceae de la Frontera" en 1859. Los problemas relacionados con estas tipificaciones oscilan desde tipificaciones de lectotipos conjuntos a tipificaciones ilegítimas de ilustraciones cuando se conocía la existencia de materiales originales. Los materiales seleccionados fueron colectados en el Estudio de la Frontera Mexicana y se encuentran actualmente depositados en el Jardín Botánico de Nueva York (NY) y el Jardín Botánico de Misuri (MO) y las ilustraciones fueron incluidas por Engelmann en su reporte sobre las Cactaceae de la Frontera de 1859.

Keywords: Chihuahuan Desert, Clavatae, Corynopuntia, Grusonia, Opuntia, Sonoran Desert. 
George Engelmann published several new taxa in the Cactaceae from the Chihuahuan and Sonoran Deserts of Mexico and the United States during the Mexican Boundary Survey. These materials were collected by Charles Wright, Arthur Schott, Frederick Wislizenus, Augustus Fendler, and Josiah Gregg among other collectors (Engelmann 1848, 1856, 1857, 1863; Soulè 1970; Stieber and Lange 1986). Given the overall work conditions that these collectors faced during their trips, it is remarkable that actual voucher specimens were produced and still exist, including the "brown paper" used to dry the plants and produce the labels (Stieber and Lange 1986). The extant original material allows the typification of names, an invaluable enterprise considering the widespread nomenclatural instability of the Cactaceae (Gibson et al. 1986; Hunt 1991). Fortunately, many of the opuntioid names published by Engelmann have a great potential to be typified with original extant material (Bárcenas and Hawkins 2007).

Engelmann had a solid scientific background in the plant sciences (Engelmann 1986; Shaw 1986; Soulè 1970), and many of the plant materials used for his descriptions are preserved today as voucher specimens at MO. Some duplicates lodged at NYTorrey Herbarium, were, probably sent by Engelmann to Torrey as the overall coordinator of botany of the Boundary Commission (Shaw 1986). Particularly good descriptions of these species were published in "Cactaceae of the Boundary" and exceptional illustrations produced by Paulus Roetter were also printed in the same report (Engelmann 1859).

Previous typifications of Opuntia bulbispina Engelman, O. clavata Engelman, O. emoryi Engelman and O. grahamii Engelman have inconsistencies and errors that need to be addressed in order to clarify the nomenclature of the group. Coulter (1896) in his "Preliminary revision of the North American species of Echinocactus, Cereus and Opuntia" mentioned some of the names published by Engelmann making reference to the types of the Opuntia species here discussed. It has been argued (Crook and Mottram 1996) that Coulter (1896) typified some names in his treatment. Although Coulter certainly stated the word "type" and in some cases the collector, year of collection and the herbarium where the voucher is deposited, his statements cannot be taken as a typification act, but more as a mechanical citation of the original materials previously studied and cited by Engelmann. That this is the case is demonstrated unequivocally by the fact that Coulter only mentioned "type not found in the Engelmann collection" when discussing Opuntia parryi, without any attempt to choose a particular specimen to designate as a type. Also, when discussing Opuntia clavata, Coulter (1896, p. 442) cited "-Type, the specimens of Wislizenus and Fendler of 1846 and 1847 in Herb. Mo. Bot. Gard.," making it clear that the two collections were independent gatherings and demonstrating no intention to typify these names. The citations of Coulter should not be taken as a typification act.

\section{Nomenclatural section: lectotypification}

Opuntia bulbispina Engelm., Proc. Amer. Acad. Arts 3: 304. 1857. 三Corynopuntia bulbispina (Engelm.) F. M. Knuth. Kaktus-ABC 115. 1936. $\equiv G r u-$ sonia bulbispina (Engelm.) H. Rob. Phytologia 26: 176. 1973. Type: MEXICO. Coahuila: Near Perros Bravos, North of Saltillo. 1848, J. Gregg 669. Lectotype, here designated: Figure 5 of Plate 73 in Engelmann 1859.

The original collection of Gregg has not been found at MO, NY, US, SRSC, ARIZ, ASU and K. Two independent photographs of the plant putatively collected by Gregg exist, one at MO (sheet 3377650) and one at NY (unnumbered sheet, but photograph is labeled as 409). There is, however, no certainty that these two photographs depict the plant collected by Gregg although both photographs agree with the illustration used by Engelmann in his Synopsis of the Cactaceae (Engelmann 1857). The original herbarium voucher has not been found although a thorough search has been implemented at $\mathrm{MO}$ (correction label by J. C. Solomon in the MO sheet 3377650).

Opuntia grabamii Engelm. Proc. Amer. Acad. Arts 3: 304. 1857. $\equiv$ Corynopuntia grahamii (Engelm.) F. M. Knuth. Kaktus-ABC 116. 1936. $\equiv$ Opuntia schottii Engelm. var. grahamii (Engelm.) L. D. Benson. Cact. Succ. J. (US). 41: 124. 1969. Type: USA. Texas: Sandy soil in the bottoms of the Rio Grande, near El Paso, and for about 100 miles along the river. 1851, Wright 10. Lectotype, here designated: $M O$ (sheet 2015356). Epitype, here designated: MO: MEXICO. Chihuahua: Vicinity of Santa Rosalía. 13 to 15 June 1908. Altitude about 1200 meters, E. Palmer 386. (MO 2511550). Isoepitypes, US, $\mathrm{K}$ and NY.

Benson (1969) incorrectly designated Wright 10 and Plate 72 in Engelmann (1859) as joint lectotypes for Opuntia grahamii, recognized by Crook and Mottram (1998) as inadmissible under article 8.1 of the ICBN that specifies that the type of a name is either a single specimen or an illustration conserved in one herbarium or other collection or institution (McNeill et al. 2006).

Crook and Mottram (1998), after recognising the flawed typification, also mentioned: "LT: Plate 72, by Paulus Roetter, in Engelmann, Cactaceae of the Boundary (1859). The original plate is lodged at the Smithsonian Institution. Designated here." Unfortunately, there is some confusion among these phrases and in the order of the wordings used by Crook and Mottram in designating the type, since it is not clear which of the two elements mentioned was chosen as the type. On the one hand, it could be the illustration, that is, Plate 72 by Roetter reproduced in Engelmann (1859), but on the other hand, it could also be the original Plate lodged at the Smithsonian Institution which was intended to serve as the lectotype. Regardless of this confusion, the lectotypification of 
Crook and Mottram (1998) is flawed under article 9.10 of the ICBN (McNeill et al. 2006) since extant original material is available at $\mathrm{MO}$ as also recognized by Crook \& Mottram (1998).

\section{Nomenclatural section: second-step lectotypifications}

Opuntia clavata Engelm. Mem. Tour N. Mex. 95. 1848. ECorynopuntia clavata (Engelm.) F. M. Knuth. Kaktus-ABC 116. 1936. 三Grusonia clavata (Engelm.) H. Rob. Phytologia 26: 176. 1973. Type: U.S.A. New Mexico: about Santa Fe, Nov. 6, 1846 , (lectotype [first-step], designated by L. Benson, The Cacti of the United States and Canada. 1982, at MO ["only flowers"]; lectotype [second-step, here designated], by R. T. Bárcenas, J. A. Hawkins \& F. Chiang: $\mathrm{MO}$ [the flowers longitudinally sectioned in the flower envelope], Fendler 275, 1847, MO).

The original materials were collected by Wislizenus around Albuquerque in 1846 and by Fendler around Santa Fe, New Mexico in 1846 and 1847. The material from Wislizenus has not been found (Benson 1982) and only the materials of Fendler are available at MO. The extant original material from Fendler was chosen by Benson (1982, p. 917) as the lectotype of Opuntia clavata Engelm. The voucher selected as lectotype was Fendler from 6 November 1846 (MO). In his designation, Benson (1982, p. 917) mentioned "only flowers" as well as considering Lyman and R. L. Benson \#14675 (POM) as the "typical specimen for vegetative parts and fruits". It is not clear if he typified Lyman and R. L. Benson 14675 (POM) as a "joint" lectotype in addition to Fendler from 6 November 1846, or if he only used the word "typical specimen" in the sense of a pure guideline for specimen comparisons. His intention should be taken as a pure guide for comparisons and not as a strict designation of a joint lectotype since he did not state "type designation" for the POM voucher as he did for the designation of Fendler from 6 November 1846 as a lectotype.

The selection of Fendler from 6 November 1846 as a type is, however, an inaccurate typification because the plant material present in the voucher is distributed in two envelopes, one with flowers and the other with seeds but from two different collection events. The lectotypification of Fendler from 6 November 1846 is invalid since, for the purpose of typification, "a specimen is a gathering, or part of a gathering, of a single species of infraespecific taxon made at one time" as specified in art. 8.2 of the ICBN (McNeill et al. 2006). The voucher from 6 November 1846 (MO 2015160) is a mixed voucher with three different labels, two different years and three different collection numbers: Fendler 6 from 1846, and Fendler 64 and Fendler 275, both from 1847.

Opuntia emoryi Engelm. Proc. Amer. Acad. Arts 3: 303. 1857. EGrusonia emoryi (Engelm.) Pinkava. J. Arizona-Nevada Acad. Sci. 32: 50. 1999.
ECorynopuntia emoryi (Engelm.) P. M. Griff. Haseltonia 9: 91. 2002. Type: [MEXICO]. [Chihuahua]. Arid soil south and west of El Paso, especially between sand hills and Lake Santa Maria, (lectotype [first-step], designated by L. Benson, The cacti of the United States and Canada. 1982, at MO ["the seeds mentioned above, MO"]; lectotype [second-step, here designated], by R. T. Bárcenas, J. A. Hawkins \& F. Chiang: MO: Bigelow s/n (MO sheet 2015170). Duplicate of lectotype NY. Epitype, here designated: Plate 70 by P. Roetter in Engelmann, "Cactaceae of the Boundary," 1859.

Benson making reference to the two vouchers at MO when typifying $O$. emoryi, stated "...the seeds mentioned above" (1982, p. 917) but did not clarify which of the two vouchers present at MO and clearly mentioned by him (MO 2015171 and MO 2015170) was chosen as the lectotype. However, he annotated only MO 2015170 as the type specimen of Opuntia emoryi and this is the reason for choosing MO 2015170 over MO 2015171.

\section{Acknowledgements}

RTB would like to acknowledge Consejo Nacional de Ciencia y Tecnología, CONACYT, Mexico, for the graduate scholarship while at the The University of Reading, UK. Also our acknowledgments to the curators and personnel of the MO, NY, US, SRSC, ARIZ, ASU and $\mathrm{K}$ herbaria for loaning their collections for study. The authors would also like to thank the reviewers for their helpful comments.

\section{Literature cited}

Bárcenas RT, Haw kins JA. 2007. The discovery of a previously unknown isotype of Opuntia vilis Rose (Opuntioideae: Cactaceae). Haseltonia 13: 1-5.

Benson L. 1969. The cacti of the United States and Canada- new names and nomenclatural combinations- I. Cactus and Succulent Journal (U.S.) 41: 124.

Benson L. 1982. The Cacti of the United States and Canada. Stanford University Press, Stanford, USA.

Coulter JM. 1896. Preliminary revision of the North American species of Echinocactus, Cereus, and Opuntia. Contributions from the U.S. National Herbarium 3: 406.

Crook R, Моттram R. 1996. Opuntia index part 2. Taxonomic note and C-E. Bradleya 14: 99-114.

Своок R, Моттram R. 1998. Opuntia index Part 4: G-H. Bradleya 16: 125.

Engelmann, G. 1848. Botanical appendix. In: Wislizenus, A. (ed.). Memoir of a tour to northern Mexico connected with Col. Doniphan's expedition, in 1846 and 1847. Tippin \& Streeper, Washington.

Engelmann G. 1856. Description of the Cactaceae. Whipple report of explorations and surveys to ascertain the most practicable and economical route for a railroad from the Mississippi River to the Pacific Ocean 4: 48-49.

Engelmann G. 1857. Synopsis of the Cactaceae of the territory of the United States and adjacent regions. 
Proceedings of the American Academy of Arts and Sciences 3: 302-305.

Engelmann G. 1859. Cactaceae of the Boundary. United States and Mexican Boundary Survey Report 2: 53-55.

Engelmann G. 1863. Additions to the cactus-flora of the United States. Transactions of the Academy of Sciences of Saint Louis 2: 201.

ENGelmann G. 1986. Instructions for the collection and preservation of botanical specimens. Annals of the Missouri Botanical Garden 73: 504-507.

Gibson AC, Spencer KC, Bajaj R, Mclaughlin JL. 1986. The ever-changing landscape of cactus systematics. Annals of the Missouri Botanical Garden 73: 532-555.

Shaw EA. 1986. Changing botany in North America: 1835-1860 the role of George Engelmann. Annals of the Missouri Botanical Garden 73: 508-519.

Soulè OH. 1970. Dr. George Engelmann: the first man of cacti and a complete scientist. Annals of the Missouri Botanical Garden 57: 135-144.

Stieber MT, Lange C. 1986. Augustus Fendler (1813-1883), professional plant collector: selected correspondence with George Engelmann. Annals of the Missouri Botanical Garden 73: 520-531. 